\title{
Be mindful of eating to be healthy people
}

Ying Gao Balch

The University of Arkansas at Pine Bluff, Department of Human Sciences

Corresponding Author: Ying Gao Balch, The University of Arkansas at Pine Bluff, Department of Human Sciences

Received date: May 13, 2021; Accepted date: May 28, 2021; Published date: June 03, 2021

Citation: Ying Gao Balch. (2021) Be mindful of eating to be healthy people. Clinical Research and Clinical Trials. 3(5); DOI: 10.31579/2693-

4779/043

Copyright: (C) 2021 Ying Gao Balch, This is an open access article distributed under the Creative Commons Attribution License, which permits unrestricted use, distribution, and reproduction in any medium, provided the original work is properly cited.

A person cannot stop eating a delicious snack until full of a snack bag of empty without consciousness; most people had this experience. The snack bag of the front of the design, which is attractive to people to buy, a load on the back has detailed the nutrition food label of a claim, and sounds are a perfect snack for us to enjoy our leisure time.

"The food industry company of the slogan is profit." In recent years, delicious snacks are the most significant food industry for a corporate business to survive. Food industry marketing isenormous and dispersed worldwide; additionally, the food industry also produces various snacks for bringing the pleasure of eating to customers. The sounds are great. However, epidemiologicalstudies have identified that chronic diseases are increasingly related to overeating snacks daily. The snack is delicious, which is undeniable. What drove a person to eat so fast and more? The answer is human instinct without human consciousness. It is the simplicity of the seemingly, but it is also a complex mechanism as human beings. That evoked people of mind how to mindfully and consciously eat to help people eat healthily.

People know that having a more healthy body and having more good experience in the lifetime. But the problem is many people are not consciously eating. When most people have a medical concern about determiner health, people always complain about how bad snacks are harming people of health by adding too many fats, sugar, and salts. As human beings need two types of foods, and physical food is to maintain body functions, the next, and food is the impressionof food through people of five senses to exist. People of feelings of sight, hearing, touch, smell, and taste tell people about the shape, texture, flavor, crispness, and food temperature. Those factorshave an impact on what people are eating. When a person eats food consciously or unconsciously,it is primarily by how it looks, smells, tastes, feels, and even sounds. Today, many people are unconsciously eating food that is causing many problems with our health issues worldwide. People can see and smell food anywhere in people of a lifetime; as humans eat full of stomachs, humans should also be aware of a healthy body. That is why a human should focus on eating the snacks consciously, being mindful of satiety, and then deciding to begin and end eating. How to developmindfulness skills to practice for achieving a healthy eating pattern? It takes time to learn and improve with practice. Consistently, train people to notice how feelings of hunger and satisfactionchange when a person eats.

Society has been lucky enough to live this time; Technology is promptly developing; the community has various marketing food choices for enjoying the snacks. People should be gratefulfor the world and try to be mindful of eating to be healthy people.
This work is licensed under Creative Commons Attribution 4.0 License

To Submit Your Article Click Here: Submit Manuscript

DOI: $10.31579 / 2642-9756 / 043$
Ready to submit your research? Choose Auctores and benefit from:

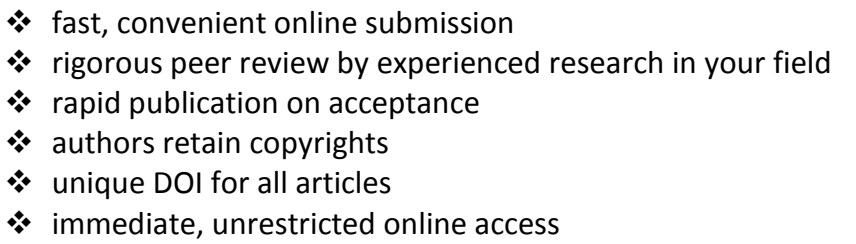

At Auctores, research is always in progress.

Learn more www.auctoresonline.org/journals/women-health-care-andissues- 